\title{
Divine Wrath and Divine Mercy in the World of Antiquity
}

\author{
Ed. by Reinhard Gregor Kratz and Hermann Spieckermann
}

[Gottes Zorn und Barmherzigkeit in der Welt der Antike.]

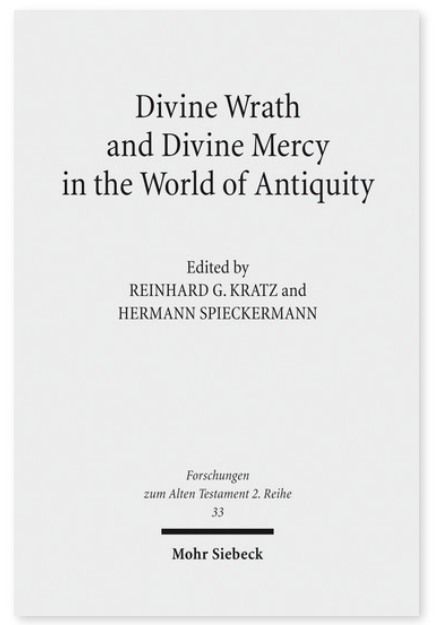

2008. VIII, 279 Seiten. FAT II 33

ISBN 978-3-16-151131-8

DOI 10.1628/978-3-16-151131-8

eBook PDF $34,00 €$

ISBN 978-3-16-149820-6

fadengeheftete Broschur 34,00€
Veröffentlicht auf Englisch.

Zorn und Barmherzigkeit gehören zu den charakteristischen Zügen vieler Gottheiten in der Welt der Antike. Sie sind ein Erklärungsversuch für Erfahrungen sowohl des Leidens und der Anfechtung als auch des Wohlergehens und der Behütung. Polytheistische Konzeptionen eröffnen eine große Vielfalt der Verhältnisbestimmung, während monotheistische Konzeptionen darauf bedacht sein müssen, das Verhältnis von Zorn und Barmherzigkeit in ein Verhältnis zu bringen, das mit dem dominierenden Gottesbild in Einklang steht. Nicht selten ist es gerade das Verhältnis von Zorn und Barmherzigkeit, das für das autoritative Gottesbild zentrale Bedeutung hat. Die vorliegenden Studien, die den komparatistischen Zugang zu den Religionen aus Orient und Antike unter dem Aspekt göttlichen Zorns und göttlicher Barmherzigkeit ermöglichen, liefern damit zugleich wichtige Einsichten in das Selbstbild der untersuchten Religionen.

\section{Inhaltsübersicht}

\section{Introduction}

Hermann Spieckermann: Wrath and Mercy as Crucial Terms of Theological Hermeneutics

Ancient Near East

Louise Gestermann: Zorn und Gnade ägyptischer Götter - Manfred Krebernik: »Wo einer in Wut ist, kann kein anderer ihm raten.« Zum göttlichen Zorn im Alten Orient - Billie Jean Collins: Divine Wrath and Mercy in the Religions of the Hittites and Hurrians - Kyle McCarter: When the Gods Lose Their Temper. Divine Rage in Ugaritic Myth and the Hypostasis of Anger in Iron Age Religion - Reinhard G. Kratz: Chemosh's Wrath and Yahweh's No. Ideas of God's Wrath in Moab and Israel - Karl William Weyde: »Has God Forgotten Mercy, in Anger Withheld his Compassion?« Names and Concepts of God in the Elohistic Psalter Antiquity

Michael Bordt Sj: Platon über Gottes Zorn und seine Barmherzigkeit - Peter Schenk: Darstellung und Funktion des Zorns der Götter in antiker Epik - Markus Witte: »Barmherzigkeit und Zorn Gottes« im Alten Testament am Beispiel des Buchs Jesus Sirach - Jörg Frey: God is Love. On the Textual Tradition and Semantics of a Core Expression of the Christian Notion of God Late Antiquity

Aharon Shemesh: An Offer God Can't Refuse. The Punishment of Flagellation in Rabbinic Theology - Gunnar af Hällström: The Wrath of God and His Followers. Early Christian Considerations - Todd Lawson: Allah's Wrath and Mercy

Reinhard Gregor Kratz Born 1957; 1987 Dr. theol., 1990 Habilitation at the University of Zürich; since 1995 Professor for Old Testament/Hebrew Bible at the Theological Faculty of the University Göttingen. https://orcid.org/0000-0002-4306-1730

Hermann Spieckermann Geboren 1950; 1969-75 Studium der Ev. Theologie und Altorientalistik in Münster und Göttingen; 1982 Promotion; 1987 Habilitation; 1989-92 Professor für Altes Testament und altorientalische Religionsgeschichte in Zürich; 1992-99 in Hamburg; 1999-2018 Inhaber des Lehrstuhls für Altes Testament in Göttingen.

Jetzt bestellen:

https://mohrsiebeck.com/buch/divine-wrath-and-divine-mercy-in-the-world-of-antiquity-9783161511318?no_cache=1 order@mohrsiebeck.com

Telefon: +49 (0)7071-923-17

Telefax: +49 (0)7071-51104 